\title{
Camelid Single-Domain Antibodies: Historical Perspective and Future Outlook
}

OPEN ACCESS

Edited by:

Marc H. V. Van Regenmortel,

Centre national de la recherche

scientifique (CNRS), France

Reviewed by:

Serge Muyldermans,

Vrije Universiteit Brussel, Belgium

Etienne Weiss,

Ecole Supérieure de Biotechnologie de Strasbourg, France

*Correspondence:

Mehdi Arbabi-Ghahroudi

mehdi.arbabighahroudi@

nrc-cnrc.gc.ca

This is NRC publication number: 53362.

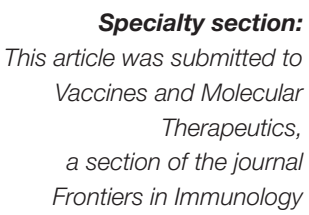

Specialty section:

This article was submitted to Vaccines and Molecular Therapeutics, a section of the journal Frontiers in Immunology

Received: 29 September 2017 Accepted: 03 November 2017 Published: 20 November 2017

Citation:

Arbabi-Ghahroudi M (2017) Camelid Single-Domain Antibodies: Historical Perspective and Future Outlook.

Front. Immunol. 8:1589. doi: 10.3389/fimmu.2017.01589

\begin{abstract}
Mehdi Arbabi-Ghahroudi, ${ }^{1,2}$
${ }^{1}$ Human Health Therapeutics Research Centre, National Research Council Canada, Ottawa, ON, Canada, ${ }^{2}$ Department of Biology, Carleton University, Ottawa, ON, Canada
\end{abstract}

Tremendous effort has been expended over the past two and a half decades to understand many aspects of camelid heavy chain antibodies, from their biology, evolution, and immunogenetics to their potential applications in various fields of research and medicine. In this article, I present a historical perspective on the development of camelid single-domain antibodies (sdAbs or $\mathrm{V}_{\mathrm{H}} \mathrm{Hs}$, also widely known as nanobodies) since their discovery and discuss the advantages and disadvantages of these unique molecules in various areas of research, industry, and medicine. Commercialization of camelid sdAbs exploded in 2001 with a flurry of patents issued to the Vrije Universiteit Brussel (VUB) and later taken on by the Vlaams Interuniversitair Instituut voor Biotechnologie (VIB) and, after 2002, the VIB-founded spin-off company, Ablynx. While entrepreneurial spirit has certainly catalyzed the exploration of nanobodies as marketable products, IP restrictions may be partially responsible for the relatively long time span between the discovery of these biomolecules and their entry into the pharmaceutical market. It is now anticipated that the first $\mathrm{V}_{\mathrm{H}} \mathrm{H}$-based antibody drug, Caplacizumab, a bivalent anti-vWF antibody for treating rare blood clotting disorders, may be approved and commercialized in $\mathbf{2 0 1 8}$ or shortly thereafter. This elusive first approval, along with the expiry of key patents, may substantially alter the scientific and biomedical landscape surrounding camelid sdAbs and pave the way for their emergence as mainstream biotherapeutics.

Keywords: camelid single-domain antibody, heavy chain antibody, $\mathrm{V}_{\mathrm{H}} \mathrm{H}$, nanobody, antibody engineering, therapeutic antibody

\section{INTRODUCTION}

The canonical view of antibodies as molecules composed of two heavy chains and two light chains was forever changed one day in 1989 following analysis of total and fractionated immunoglobulin G (IgG) molecules in the serum of a dromedary camel in the laboratory of Professor Raymond Hamers at the Vrije Universiteit Brussel (VUB). The serendipitous discovery of antibodies lacking a light chain [heavy chain-only antibodies (HCAbs)] occurred as part of a student-run project aimed at developing a serodiagnostic test for trypanosome infection in camels and water buffalos. The preliminary data showed that besides conventional IgG1 (MW $\sim 150 \mathrm{kDa}$ ), two other immunoglobulin fractions (thereafter called IgG2 and IgG3; MW $\sim 90 \mathrm{kDa}$ ) were present which contributed up to $75 \%$ of all serum IgGs (1-3). Comparative studies on the sera of new world camelids (Lama glama and Lama pacos) subsequently confirmed the presence of HCAbs, albeit at concentrations between 
30 and $50 \%(1,4-8)$. Following these exciting findings, it became essential to analyze the antigen-binding properties of these IgG fractions since the presence of truncated forms of heavy chain antibodies with no light chains, classically described as "heavy chain disease," had been reported in human patients $(9,10)$. No functional activity was reported for the pathogenic heavy chain antibodies in these patients, as these proteins were shown to bear extensive internal deletions in the variable $(\mathrm{VH})$ and the first constant region (CH1) domains. By contrast, antibodies from camelids exposed to Trypanosoma evansi demonstrated strong binding activity in the IgG2 and IgG3 heavy chain-only fractions as shown by radio-immunoprecipitation and blotting experiments (1).

In two subsequent reports, phage-display technology and high-resolution crystallography were utilized to (a) build a phage-display library from the lymphocytes of immunized camels and isolate monomeric antigen-specific $\mathrm{V}_{\mathrm{H}} \mathrm{H}$ domains in the absence of the constant regions (11) and (b) solve crystal structures of an unliganded $\mathrm{V}_{\mathrm{H}} \mathrm{H}$ (12) and a $\mathrm{V}_{\mathrm{H}} \mathrm{H}$ :lysozyme complex, reported simultaneously by the VUB team and a Dutch-French research group (13). The term $\mathrm{V}_{\mathrm{H}} \mathrm{H}$ was originally introduced by the VUB team in 1994 to indicate a VH domain derived from camelid heavy chain antibodies. The feasibility of isolating stable and soluble $\mathrm{V}_{\mathrm{H}} \mathrm{H}$ domains with nanomolar affinities against lysozyme and tetanus toxoid showed very early on the promise of these molecules as high-affinity binding moieties. Crystallography studies revealed additional salient features of an anti-lysozyme $\mathrm{V}_{\mathrm{H}} \mathrm{H}$, including deep penetration of its long third complementarity-determining region (CDR3) into the active site of the enzyme; this feature had rarely been seen with conventional antibodies and required a fundamental deviation from known human canonical CDR1 structure (13). Further evidence of the unique antigen recognition behavior of $\mathrm{V}_{\mathrm{H}} \mathrm{H}$ domains (including enzyme inhibition) was published over the next several years $(11,14,15)$, suggesting that $\mathrm{V}_{\mathrm{H}} \mathrm{Hs}$ might probe different sets of epitopes on proteins compared with conventional antibodies. Key proof of concept for producing bivalent/bispecific $\mathrm{V}_{\mathrm{H}} \mathrm{H}$ modalities via genetic fusion (using camelid short and long hinge sequences) of anti-lyzozyme and/or anti-tetanus toxin $\mathrm{V}_{\mathrm{H}} \mathrm{H}$ s was also established very early on (14).

\section{MOLECULAR ONTOGENY OF CAMELID HCAbs}

Molecular biology techniques were subsequently applied to decipher the DNA sequences of HCAbs. The sequencing results showed that nature had designed HCAbs as an additional arm of the immune systems of camelid ungulates over the course of their evolutionary history. The consensus of these studies suggested camelid HCAbs possessed: (a) no $\mathrm{CH} 1$ domain, and therefore, a direct connection of the rearranged $\mathrm{V}_{\mathrm{H}} \mathrm{H}$ exon to the hinge region; (b) one of two types of long (IgG2) and short (IgG3) hinge isotypes; (c) specific conserved amino acid substitutions in framework region 2 (FR2), mainly at $\mathrm{VH}$ positions that make contact with the VL in classical antibodies, including Kabat positions 37, 44, 45, and 47; and (d) potentially different CDR3 amino acid composition and a broader length distribution for CDR3 compared to the heavy chains of conventional antibodies $(1,16,17)$.

Later genomic studies shed light on the origin of HCAbs in dromedary camels and alpacas. It is now established that HCAbs are produced from the same igh locus as conventional antibodies but with distinct sets of genes for the generation of HCAbs. It is estimated that alpaca and dromedary genomes contain $\sim 17$ and $\sim 40 \mathrm{~V}_{\mathrm{H}} \mathrm{H}$ genes, respectively, with an identical organization of the genes that produce conventional antibodies $(18,19)$. The $\mathrm{CH} 1$ exon is present in the genomic DNA of HCAbs but a point mutation ( $\mathrm{G}$ to $\mathrm{A}$ ) at the $5^{\prime}$ end of the $\mathrm{CH} 1$-hinge intron disrupts the consensus splicing site (GT) and causes omission of this region during splicing $(3,18,20-22)$. A complete picture of camelid germline $\mathrm{V}$ gene repertoires of heavy and light chains and the classification of $\mathrm{VH}$ and $\mathrm{V}_{\mathrm{H}} \mathrm{H}$ genes is still missing. Published genomic and cDNA data have so far shown that camelid $\mathrm{V}_{\mathrm{H}} \mathrm{H}$ genes are highly homologous to the human $\mathrm{VH} 3$ family of clan III with the exception of several key amino acid substitutions in FR2, namely, Val37 $\rightarrow$ Phe/Tyr, Gly44 $\rightarrow$ Glu, Leu45 $\rightarrow$ Arg, and Trp47 $\rightarrow$ Gly (Kabat numbering), and are encoded by a distinct subset of germline $\mathrm{V}$ genes. Preliminary investigations of published llama $\mathrm{V}_{\mathrm{H}} \mathrm{H}$ sequences classified them into four subfamilies by sequence similarity, and many of the earliest-described $\mathrm{V}_{\mathrm{H}} \mathrm{H}$ features such as long CDR3s, additional disulfide bridges, and particular canonical structures of CDR1-3 were shown to be subfamily specific $(17,23)$. Subsequent studies in alpaca identified at least three $\mathrm{V}$ gene subgroups of the alpaca igh locus: IGHV1, IGHV2, and IGHV3 which are equivalent to the human IGHV families within clan I (VH families 2, 4, 6), II (VH families 1, 5, 7), and III (VH family 3), respectively, based on sequence homology. The alpaca $\mathrm{V}_{\mathrm{H}} \mathrm{H}$ genes clustered into six subsets by sequence similarity, but all are homologous to human IGHV3 genes (18). Furthermore, recent investigations have demonstrated the presence of genes belonging to IGHV families 1,3 , and 4 (human clan I and III) in llama and alpaca, and in addition, uncovered new camelid $\mathrm{V}$ genes highly homologous to the human IGHV5 and IGHV7 families (human clan II); however, no genes similar to human families 2 or 6 (within human clan I) were found (24). Interestingly, a novel promiscuous class of $\mathrm{V}$ genes in camelids was identified that is closely related to the human VH4 family (clan I). These VH4 homologs contribute largely to the classical antibody repertoire and lack the hallmark solubilizing $\mathrm{V}_{\mathrm{H}} \mathrm{H}$ residues in FR2. Nevertheless, antigen-specific VH4-family fragments with $\mathrm{V}_{\mathrm{H}} \mathrm{H}$-like stability and solubility were isolated from an immune llama library (25). In the absence of a complete set of camelid germline $\mathrm{VH}$ and $\mathrm{V}_{\mathrm{H}} \mathrm{H}$ genes, most immunogenetic studies have relied on comparisons with human germline genes.

The consensus of immunogenetic studies of camelid HCAbs is that repertoire diversification of these molecules may involve (a) a large number of unique $\mathrm{V}_{\mathrm{H}} \mathrm{H}$ gene segments recombining with $\mathrm{DH}$ and $\mathrm{JH}$ minigenes, possibly with additional nontemplated nucleotide insertions leading to longer CDR3 loops; (b) somatic hypermutation, potentially of extended CDR1 regions compared with conventional antibodies; (c) acquisition of non-canonical cysteine residues in the CDRs and FR2; and 
(d) involvement of FR2 residues in antigen binding and in structuring the CDR3 loop $(3,22,26,27)$. In agreement with immunogenetic analyses, several structural studies have suggested that due to the loss of VL domains, $\mathrm{V}_{\mathrm{H}} \mathrm{H}$ paratopes have acquired a higher structural complexity by involving more residues in antigen binding compared to classical VHs (27). As for the evolutionary origin of HCAbs, it is difficult to draw solid conclusions but several hypotheses have been proposed. A common theme among most of these has been the need for generating or expanding a new antigen-binding repertoire in Camelidae to address certain antigenic challenges, e.g., cryptic epitopes of commonly encountered pathogens. Phylogenetic analyses have confirmed that HCAbs diverged from conventional antibodies as a result of recent adaptive changes (22, 27-29).

\section{HISTORY OF THE DEVELOPMENT OF CAMELID SINGLE-DOMAIN ANTIBODIES (sdAbs) AS THERAPEUTICS}

Prior to the discovery of HCAbs, a single report describing the concept of sdAbs was published by Sally Ward and colleagues in 1989 (30), when they showed that VH domains from an immunized mouse, in the absence of a VL domain, could bind specifically to lysozyme and keyhole limpet hemocyanin. However, poor VH domain stability and solubility, as well as weak antigen-binding affinity compared to its fragment variable region counterpart $(\mathrm{Fv})$ or to the parent antibody, were major impediments to any commercial applications (Figure 1).

From a historical perspective, development of camelid $\mathrm{V}_{\mathrm{H}} \mathrm{Hs}$ as drugs has gone through three major phases. The first 10 years (1993-2003) can be classified as the exploratory phase, which coincided with the founding of Ablynx in December 2001 as a spin-off company from the Vlaams Interuniversitair Instituut voor Biotechnologie. The main developments in the first decade included: (i) the first description of $\mathrm{V}_{\mathrm{H}} \mathrm{Hs}$ (1); (ii) sequence analyses of $\mathrm{V}_{\mathrm{H}} \mathrm{Hs}$ with identification of $\mathrm{V}_{\mathrm{H}} \mathrm{H}$ germline gene segments and classification of $\mathrm{V}_{\mathrm{H}} \mathrm{H}$ gene subfamilies (16, 20, 23); (iii) adaptation of phage-display technology to $\mathrm{V}_{\mathrm{H}} \mathrm{Hs}$ (11) and isolation of antigen-specific $\mathrm{V}_{\mathrm{H}} \mathrm{Hs}$, including several enzyme inhibitors $(12,15)$; (iv) solving the crystal structure of several $\mathrm{V}_{\mathrm{H}} \mathrm{H}$ :antigen complexes $(13,31-34)$; (v) development of methods for expression of $\mathrm{V}_{\mathrm{H}} \mathrm{Hs}$ in bacteria and yeast systems and for biophysical characterization of $\mathrm{V}_{\mathrm{H}} \mathrm{Hs}(35,36)$; and (vi) the use of $\mathrm{V}_{\mathrm{H}} \mathrm{Hs}$ as reagents in immunoaffinity purification and immuno-perfusion (37).

During the second phase of development (2003-2013), $\mathrm{V}_{\mathrm{H}} \mathrm{Hs}$ began to receive more attention and publications in this area grew dramatically, surpassing 1,000 by 2013 [Ref. (38) and personal investigation on Web of Science]. Interestingly, a large and diverse group of countries and institutions (close to 50) were responsible for research on camelid $\mathrm{V}_{\mathrm{H}} \mathrm{Hs}$ during this time, mainly for the purpose of exploring their potential applications in research, biotechnology, and medicine (38). The major hallmark of this decade was the start of preclinical and clinical studies of several nanobodies by Ablynx and others as therapeutics and imaging reagents $(39,40)$, including $\mathrm{V}_{\mathrm{H}} \mathrm{Hs}$ against (i) blood glycoprotein vWF to control platelet aggregation and clot formation; (ii) viral infection (RSV); (iii) venom toxins; (iv) IL6-R for treatment of rheumatoid arthritis; and (v) the use of radiolabeled nanobodies for Her2+ tumor imaging. There were major technological advancements made in the expression of $\mathrm{V}_{\mathrm{H}} \mathrm{Hs}$ in heterologous systems and in creating an array of bi- and multivalent $\mathrm{V}_{\mathrm{H}} \mathrm{Hs}$ with superior efficacy during this decade.

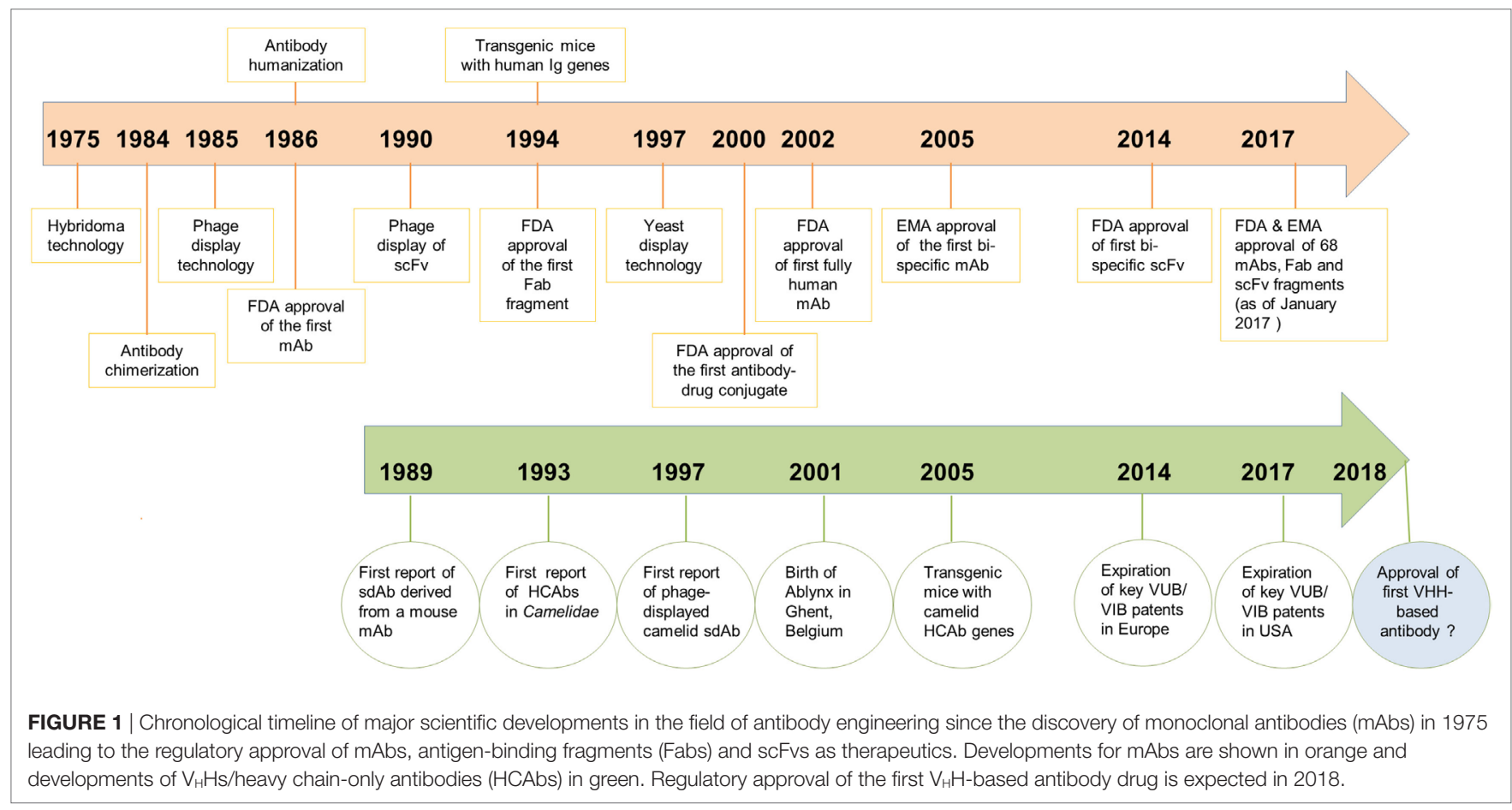


Now in the third phase of development (2014-present), publications continue to grow and more $\mathrm{V}_{\mathrm{H}} \mathrm{Hs}$ have entered into clinical trials or advanced closer to the market. The main patent claims on camelid antibody fragments expired in the summer of 2014 in Europe and in the summer of 2017 in America. Ablynx has expanded its collaborations with large biophama players, such as Merck, Boehringer Ingelheim, Sanofi, and so on, with more than 20 preclinical and clinical programs. It is expected that the first $\mathrm{V}_{\mathrm{H}} \mathrm{H}$-based drug (Caplacizumab; bivalent anti-vWF nanobody for treating rare blood clotting disorders) will reach the market sometime in 2018 (www.ablynx.com). Meanwhile, IP limitations on the composition of matter of $\mathrm{V}_{\mathrm{H}} \mathrm{Hs}$ are diminishing and more biotechnology companies (39) are showing interest in commercialization of these domain antibodies as therapeutics, diagnostics, and research reagents (Figure 1).

\section{CAMELID sdAbs: PROS, CONS, AND APPLICATIONS}

Immunization of Camelidae against targets of interest leads to the in vivo maturation of $\mathrm{HCAb}$ and conventional antibody repertoires. Construction of phage-display libraries is performed by cloning of amplified $\mathrm{V}_{\mathrm{H}} \mathrm{H}$ repertoires with minimal modification, thus presenting an authentic picture of in vivo-matured heavy chain repertoire diversity. By contrast, in both scFv libraries (requiring the artificial joining of $\mathrm{VH}$ and $\mathrm{VL}$ domains by a synthetic linker) and antigen-binding fragment (Fab) libraries derived from conventional antibody repertoires, natural VH-VL pairings are usually lost. The potential for direct cloning of $\mathrm{V}_{\mathrm{H}} \mathrm{H}$ repertoires from immunized camelids, the smaller library sizes required to capture the immune $\mathrm{V}_{\mathrm{H}} \mathrm{H}$ repertoire, the stability of the libraries, the feasibility of displaying $\mathrm{V}_{\mathrm{H}} \mathrm{Hs}$ on a phage or alternative display formats, and the ease of sub-cloning and expression of antigen-specific $\mathrm{V}_{\mathrm{H}} \mathrm{Hs}$ are among the major technical advantages of the camelid $\mathrm{V}_{\mathrm{H}} \mathrm{H}$ platform over conventional antibody platforms.

Key characteristics of $\mathrm{V}_{\mathrm{H}} \mathrm{Hs}$ include their high affinity and specificity (equivalent to conventional antibodies), high thermostability, good solubility and strictly monomeric behavior, small size ( $2.5 \mathrm{~nm}$ in diameter and about $4 \mathrm{~nm}$ in length; $\sim 15 \mathrm{kDa}$ ), relatively low production cost, ease of genetic engineering, format flexibility or modularity, low immunogenicity, and a higher penetration rate into tissues $(3,41-44)$. The short half-life of $\mathrm{V}_{\mathrm{H}} \mathrm{Hs}$ in blood circulation is well suited to certain applications such as tumor imaging or delivery of toxin or radioisotopes to diseased tissues where rapid clearance is required. However, the pharmacokinetic behavior of $\mathrm{V}_{\mathrm{H}} \mathrm{Hs}$ can also be improved by extending their half-lives using different formatting options, including PEGylation or fusion to serum albumin or an antiserum albumin moiety $(43,45,46)$. The immunogenicity of $\mathrm{V}_{\mathrm{H}} \mathrm{Hs}$ domains can also be minimized by humanization (47-49). As with all antibodies of non-human species origin (and even fully human antibodies), immunogenicity and toxicity must be investigated empirically for humanized $\mathrm{V}_{\mathrm{H}} \mathrm{Hs}$. A complete picture of the immunogenicity of non-humanized and humanized camelid $\mathrm{V}_{\mathrm{H}} \mathrm{Hs}$ is lacking due to insufficient data, but anti-drug immune responses may have been a major reason for the clinical failure of a humanized tetravalent Nanobody ${ }^{\circledR}$ targeting the DR5 receptor (50). As of 2016, $\mathrm{V}_{\mathrm{H}} \mathrm{Hs}$ have been isolated against more than 120 therapeutically important targets relevant to oncology, in vivo imaging, hematology, infectious diseases, neurological, and inflammatory disorders, with some in advanced stages of clinical trials (39).

One of the unique characteristics of $\mathrm{V}_{\mathrm{H}} \mathrm{Hs}$ is their ability to target antigenic epitopes at locations which are difficult to access by large molecules such as conventional monoclonal antibodies (mAbs). Examples include intracellular targets (51, 52) or epitopes concealed from mAbs in protein structures (53), G protein-coupled receptors (54,55), and ion channels (3). $\mathrm{V}_{\mathrm{H}} \mathrm{Hs}$ are ideally suited for such applications due to their small size, target specificity, and long CDR3 loops, bypassing many drawbacks related to small-molecule synthetic drugs such as fine specificity and off-target toxicity (56). As "intrabodies," $\mathrm{V}_{\mathrm{H}} \mathrm{Hs}$ are also ideally suited for cytosolic expression due to their ability to fold in the reducing intracellular environment. This feature likely reflects the single disulfide linkage present in the $\mathrm{V}_{\mathrm{H}} \mathrm{H}$ domain, as compared to the multi-domain structure and multiple disulfide linkages of conventional antibodies, and may not be completely general to all $\mathrm{V}_{\mathrm{H}} \mathrm{Hs}$ but appears to be quite common; intracellular expression of $\mathrm{V}_{\mathrm{H}} \mathrm{Hs}$ has been widely and productively exploited for in vivo cellular imaging $(5,57)$ as well as to inhibit the function of viral proteins $(58,59)$. There have been several excellent reviews covering $\mathrm{V}_{\mathrm{H}} \mathrm{H}$ applications in different areas of basic and applied research and a detailed description of each application is beyond the scope of this article $(3,39,41,43,57,60-65)$.

$\mathrm{V}_{\mathrm{H}} \mathrm{Hs}$ are also well suited in the generation of bi- and multispecific antibodies. In the field of antibody therapeutics, it is now widely accepted that monotherapy of cancer and other diseases may not result in effective outcomes, in particular due to the problem of acquired resistance $(66,67)$. Bispecific antibodies provide a possible solution in which they could bind simultaneously to a tumor-associated antigen and another activating molecule, e.g., CD3 on T cells, leading to tumor killing/lysis through lymphocyte recruitment, or alternatively, could target two or more tumor epitopes (bi-paratopic) or antigens simultaneously. Bispecific $\mathrm{V}_{\mathrm{H}} \mathrm{Hs}$ may be uniquely positioned for these applications given their simple design and small size relative to other antibody fragments, which may result in better solid tumor penetration rates, homogeneous production at high yield in microbial systems, and ease of fusion to a heterodimerization motif, therefore bypassing issues related to some linker peptides such as aggregation and immunogenicity (45, 66, 68, 69). Interestingly, all of the $\mathrm{V}_{\mathrm{H}} \mathrm{H}$-based therapeutic candidates in clinical trials are composed of bivalent, trivalent, or higher valency formats (39). It has been shown that some $\mathrm{V}_{\mathrm{H}} \mathrm{Hs}$, when properly selected, are able to transmigrate through human brain endothelial cell layers spontaneously and, possibly through a receptor-mediated process (70-72); bispecific molecules incorporating these $\mathrm{V}_{\mathrm{H}} \mathrm{Hs}$ can, thus, deliver attached cargo (e.g., therapeutics) into the brain in rodents (73).

Despite the many advantages of $\mathrm{V}_{\mathrm{H}} \mathrm{Hs}$, there are several drawbacks to be considered as well. The fact that the antigen-binding 
paratope of camelid HCAbs has been restricted to a single domain of about 110 amino acids will automatically put more weight on each and every residue in the $\mathrm{V}_{\mathrm{H}} \mathrm{H}$ domain. The extended CDR1, longer CDR3, involvement of FR2 in antigen binding and shaping the CDR3 loop, the role of the "CDR4" (residues 76-80) loop in antigen binding, and extensive somatic hypermutation are some of the evolutionary mechanisms adapted to compensate repertoire diversity due to the lack of a VL domain (3). Therefore, there may be limitations on the extent of manipulation and engineering that can be tolerated by antigen-specific $\mathrm{V}_{\mathrm{H}} \mathrm{Hs}$. For example, complete humanization of camelid $\mathrm{V}_{\mathrm{H}} \mathrm{Hs}$ involving the mutation of residues outside the antigen-binding loops often drastically compromises antigenbinding affinity, $\mathrm{V}_{\mathrm{H}} \mathrm{H}$ stability, and the expression yield (unpublished data). A survey of the literature clearly demonstrates that almost all $\mathrm{V}_{\mathrm{H}} \mathrm{Hs}$ isolated to date have originated from direct camelid immunization, or from large naïve camelid libraries, although recently, successful isolation of $\mathrm{V}_{\mathrm{H}} \mathrm{Hs}$ from synthetic or semi-synthetic libraries against a number of protein antigens has also been reported (74-77). All available pieces of evidence support the notion that the $\mathrm{V}_{\mathrm{H}} \mathrm{H}$ domain is a highly complex molecule and that each amino acid (depending on its position) may have direct and indirect effects on the molecule's stability and structural integrity, as well as on antigen-binding affinity and specificity.

Another limitation of $\mathrm{V}_{\mathrm{H}} \mathrm{Hs}$ is their low propensity to bind small molecules, likely due to their dominant convex surface topology as compared to the flat or concave topologies found on conventional antibody fragments (e.g., scFv, Fab). In a number of llama immunization trials, we and others have been able to generate strong conventional immune responses, but rather weak HCAb responses, against several haptens and carbohydrate antigens (unpublished data). However, repeated immunization of camelids with small molecules conjugated or fused to larger proteins has led to the successful isolation of $\mathrm{V}_{\mathrm{H}} \mathrm{Hs}$ against caffeine (78), red dye (79), and linear peptides $(80,81)$ with affinities ranging from micromolar to low nanomolar. The biophysicochemical properties of $\mathrm{V}_{\mathrm{H}} \mathrm{Hs}$ suggest that they would be well suited to many immunodiagnostic platforms for detecting small molecules and environmental chemicals; however, isolation of high-affinity $\mathrm{V}_{\mathrm{H}} \mathrm{Hs}$ suitable for such applications seems to be a difficult task, although not impossible $(3,64,65,78,82,83)$. Immunization of large animals and heterogeneity in immune responses among individual outbred animals is another consideration which is important when alternative immunization techniques such as DNA immunization are applied. DNA immunization has had limited success in camelid and other large animals and reproducibility is often a major issue to be tackled (84-87). To overcome this limitation, transgenic mice bearing either a rearranged dromedary $\gamma 2$ a chain or hybrid llama/human antibody loci have been generated that produce a form of dromedary or human heavy chain antibodies (88-90).

\section{CAMELID sdAbs VERSUS mAbs}

The first therapeutic mAb, Orthoclone OKT3, a murine IgG2a for the prevention of kidney transplant rejection, hit the market little more than a decade after the discovery of hydridoma technology in 1975 (91-94). Currently, mAbs constitute about half of marketed biological products and, as of January 2017, 68 $m A b s$ have been approved by the Food and Drug Administration (FDA) in the USA and/or by the European Medicine Agency (EMA) in Europe. The projected global sales of mAbs will be close to $\$ 100$ billion in $2017(44,95)$. The lack of restrictive IP on the original technology is considered by many as a driving force that allowed researchers to develop effective research tools and diagnostic mAb-based reagents without limitation. The introduction of antibody fragments, such as Fab and scFv (the "second generation" of antibodies), combined with the power of phage-display technology in the late 1990s, opened new horizons in the world of antibodies and empowered researchers with the ability to clone the entire immunoglobulin repertoire of mammalian immune B cells and to isolate specific antibody fragments virtually against any target (96-98). This technology led to the development of the first FDA-approved fully human mAb, Humira, which was obtained from a phagedisplayed human antibody library 12 years after the initial paper by McCafferty and co-workers on the construction of phage-displayed human antibody libraries (99-101). Further developments in antibody engineering have so far resulted in three FDA-approved therapeutic Fabs (95).

Overwhelming evidence in the literature suggests that camelid $\mathrm{V}_{\mathrm{H}} \mathrm{Hs}$, as the so-called "third generation" of antibodies, have many added features that supersede those of conventional $\mathrm{mAbs}$ and antibody fragments (Fab and $\mathrm{scFv}$ ). Although $\mathrm{V}_{\mathrm{H}} \mathrm{Hs}$ have already been commercialized for non-medical applications $(63,102)$, the research and medical communities eagerly await the first $\mathrm{V}_{\mathrm{H}} \mathrm{H}$-based therapeutic to gain approval. If we consider the 9- to 13-year time span between the discovery of the key technology enabling conventional mAbs (hybridoma technology) and the FDA-approval of a mAb or an antibody fragment, a longer time has been required for the development of the first $\mathrm{V}_{\mathrm{H}} \mathrm{H}$-based therapeutic. It is unclear if technical challenges, regulatory hurdles, or the need to define a unique niche/indication for $\mathrm{V}_{\mathrm{H}} \mathrm{Hs}$, have been involved in the prolonged delay of the first $\mathrm{V}_{\mathrm{H}} \mathrm{H}$-based therapeutic. It is obvious that issues related to downstream processing, stability, immunogenicity, toxicity, safety, and potency of a $\mathrm{V}_{\mathrm{H}} \mathrm{H}$-based therapeutic product will be doubly scrutinized by FDA and EMA since it would represent the first product of its kind to enter the market. The fact that the first potential Ablynx product is an engineered bivalent anti-vWF nanobody and is produced in a microbial system may have raised additional red flags for the approving regulatory bodies.

\section{CONCLUDING REMARKS}

Over a quarter century has passed since the first observation by Hamers and colleagues of camelid HCAbs. This finding was a significant milestone in the field of antibody engineering and opened many new opportunities and applications. It was also instrumental in reviving the concept of sdAbs, which had been originally suggested by Ward et al. a few years earlier. The unique and extraordinary features of HCAbs and their antigen-binding 
domains $\left(\mathrm{V}_{\mathrm{H}} \mathrm{Hs}\right)$ have with no doubt attracted many researchers and commercial entities to the field of antibody engineering. $\mathrm{V}_{\mathrm{H}} \mathrm{Hs}$ are now closer than ever to approval as pharmaceutical drugs to fight a wide range of diseases, including cancer, inflammation, hematology, and respiratory diseases, with five $\mathrm{V}_{\mathrm{H}} \mathrm{H}$-based drugs in various stages of clinical development. $\mathrm{V}_{\mathrm{H}} \mathrm{Hs}$ have also been shown to be effective as therapeutics against infectious disease, particularly in viral therapy, as well as robust reagents in the field of diagnostic and imaging applications. While the commercial applications of $\mathrm{V}_{\mathrm{H}} \mathrm{Hs}$ have been slowed by IP limitations, it is probable that demand, as well as extensive research on these antibody domains, will ultimately supersede these limitations and bring many more of these molecules into use as biopharmaceutical reagents within the next decade.

\section{REFERENCES}

1. Hamers-Casterman C, Atarhouch T, Muyldermans S, Robinson G, Hamers C, Songa EB, et al. Naturally occurring antibodies devoid of light chains. Nature (1993) 363:446-8. doi:10.1038/363446a0

2. Wernery U. Camelid immunoglobulins and their importance for the newborn - a review. J Vet Med B Infect Dis Vet Public Health (2001) 48:561-8. doi:10.1111/j.1439-0450.2001.00478.x

3. Muyldermans S. Nanobodies: natural single-domain antibodies. Annu Rev Biochem (2013) 82:775-97. doi:10.1146/annurev-biochem-063011092449

4. van der Linden R, de Geus B, Stok W, Bos W, van Wassenaar D, Verrips T, et al. Induction of immune responses and molecular cloning of the heavy chain antibody repertoire of Lama glama. J Immunol Methods (2000) 240:185-95. doi:10.1016/S0022-1759(00)00188-5

5. Rothbauer U, Zolghadr K, Tillib S, Nowak D, Schermelleh L, Gahl A, et al. Targeting and tracing antigens in live cells with fluorescent nanobodies. Nat Methods (2006) 3:887-9. doi:10.1038/nmeth953

6. Maass DR, Sepulveda J, Pernthaner A, Shoemaker CB. Alpaca (Lama pacos) as a convenient source of recombinant camelid heavy chain antibodies ( $\mathrm{V}_{\mathrm{H}} \mathrm{Hs}$ ). JImmunol Methods (2007) 324:13-25. doi:10.1016/j.jim.2007. 04.008

7. De Simone EA, Saccodossi N, Ferrari A, Leoni J. Development of ELISAs for the measurement of IgM and IgG subclasses in sera from llamas (Lama glama) and assessment of the humoral immune response against different antigens. Vet Immunol Immunopathol (2008) 126:64-73. doi:10.1016/j. vetimm.2008.06.015

8. Blanc MR, Anouassi A, Ahmed Abed M, Tsikis G, Canepa S, Labas V, et al. A one-step exclusion-binding procedure for the purification of functional heavy-chain and mammalian-type gamma-globulins from camelid sera. Biotechnol Appl Biochem (2009) 54:207-12. doi:10.1042/BA20090208

9. Franklin EC, Lowenstein J, Bigelow B, Meltzer M. Heavy chain disease - a new disorder of serum gamma-globulins: report of the first case. Am J Med (1964) 37:332-50. doi:10.1016/0002-9343(64)90191-3

10. Alexander A, Steinmetz M, Barritault D, Frangione B, Franklin EC, Hood L, et al. gamma heavy chain disease in man: cDNA sequence supports partial gene deletion model. Proc Natl Acad Sci U S A (1982) 79:3260-4. doi:10.1073/ pnas.79.10.3260

11. Arbabi Ghahroudi M, Desmyter A, Wyns L, Hamers R, Muyldermans S. Selection and identification of single domain antibody fragments from camel heavy-chain antibodies. FEBS Lett (1997) 414:521-6. doi:10.1016/ S0014-5793(97)01062-4

12. Spinelli S, Frenken L, Bourgeois D, de Ron L, Bos W, Verrips T, et al. The crystal structure of a llama heavy chain variable domain. Nat Struct Biol (1996) 3:752-7. doi:10.1038/nsb0996-752

13. Desmyter A, Transue TR, Ghahroudi MA, Thi MH, Poortmans F, Hamers R, et al. Crystal structure of a camel single-domain VH antibody fragment in complex with lysozyme. Nat Struct Biol (1996) 3:803-11. doi:10.1038/nsb0996-803

\section{AUTHOR CONTRIBUTIONS}

MA-G conceived and wrote the manuscript.

\section{ACKNOWLEDGMENTS}

The author gratefully acknowledges Greg Hussack, Roger MacKenzie, Kevin Henry, and Kristin Kemmerich for reading and providing comments on the text.

\section{FUNDING}

This work was supported by funding from the National Research Council Canada.

14. Arbabi Ghahroudi M. Generation and Characterization of Phage-Displayed Camel Single-Domain Antibodies [Ph.D. Dissertation]. Brussels (Belgium): Vrije Universiteit Brussel (VUB) (1996).

15. Lauwereys M, Arbabi Ghahroudi M, Desmyter A, Kinne J, Holzer W, De Genst E, et al. Potent enzyme inhibitors derived from dromedary heavychain antibodies. EMBO J (1998) 17:3512-20. doi:10.1093/emboj/17.13.3512

16. Muyldermans S, Atarhouch T, Saldanha J, Barbosa JA, Hamers R. Sequence and structure of $\mathrm{VH}$ domain from naturally occurring camel heavy chain immunoglobulins lacking light chains. Protein Eng (1994) 7:1129-35. doi:10.1093/protein/7.9.1129

17. Vu KB, Ghahroudi MA, Wyns L, Muyldermans S. Comparison of llama VH sequences from conventional and heavy chain antibodies. Mol Immunol (1997) 34:1121-31. doi:10.1016/S0161-5890(97)00146-6

18. Achour I, Cavelier P, Tichit M, Bouchier C, Lafaye P, Rougeon F. Tetrameric and homodimeric camelid IgGs originate from the same IgH locus. J Immunol (2008) 181:2001-9. doi:10.4049/jimmunol.181.3.2001

19. Nguyen VK, Hamers R, Wyns L, Muyldermans S. Camel heavy-chain antibodies: diverse germline $\mathrm{V}_{\mathrm{H}} \mathrm{H}$ and specific mechanisms enlarge the antigen-binding repertoire. EMBO J (2000) 19:921-30. doi:10.1093/ emboj/19.5.921

20. Nguyen VK, Muyldermans S, Hamers R. The specific variable domain of camel heavy-chain antibodies is encoded in the germline. J Mol Biol (1998) 275:413-8. doi:10.1006/jmbi.1997.1477

21. De Genst E, Saerens D, Muyldermans S, Conrath K. Antibody repertoire development in camelids. Dev Comp Immunol (2006) 30:187-98. doi:10.1016/j.dci.2005.06.010

22. Conrath KE, Wernery U, Muyldermans S, Nguyen VK. Emergence and evolution of functional heavy-chain antibodies in Camelidae. Dev Comp Immunol (2003) 27:87-103. doi:10.1016/S0145-305X(02)00071-X

23. Harmsen MM, Ruuls RC, Nijman IJ, Niewold TA, Frenken LG, de Geus B. Llama heavy-chain $\mathrm{V}$ regions consist of at least four distinct subfamilies revealing novel sequence features. Mol Immunol (2000) 37:579-90. doi:10.1016/S0161-5890(00)00081-X

24. Klarenbeek A, El Mazouari K, Desmyter A, Blanchetot C, Hultberg A, de Jonge $\mathrm{N}$, et al. Camelid Ig $\mathrm{V}$ genes reveal significant human homology not seen in therapeutic target genes, providing for a powerful therapeutic antibody platform. MAbs (2015) 7:693-706. doi:10.1080/19420862.2015.10 46648

25. Deschacht N, De Groeve K, Vincke C, Raes G, De Baetselier P, Muyldermans S. A novel promiscuous class of camelid single-domain antibody contributes to the antigen-binding repertoire. J Immunol (2010) 184:5696-704. doi:10.4049/ jimmunol.0903722

26. Muyldermans S. Single domain camel antibodies: current status. J Biotechnol (2001) 74:277-302.

27. Nguyen VK, Su C, Muyldermans S, van der Loo W. Heavy-chain antibodies in Camelidae; a case of evolutionary innovation. Immunogenetics (2002) 54:39-47. doi:10.1007/s00251-002-0433-0

28. Daley LP, Gagliardo LF, Duffy MS, Smith MC, Appleton JA. Application of monoclonal antibodies in functional and comparative investigations 
of heavy-chain immunoglobulins in new world camelids. Clin Diagn Lab Immunol (2005) 12:380-6.

29. Flajnik MF, Deschacht N, Muyldermans S. A case of convergence: why did a simple alternative to canonical antibodies arise in sharks and camels? PLoS Biol (2011) 9:e1001120. doi:10.1371/journal.pbio.1001120

30. Ward ES, Gussow D, Griffiths AD, Jones PT, Winter G. Binding activities of a repertoire of single immunoglobulin variable domains secreted from Escherichia coli. Nature (1989) 341:544-6. doi:10.1038/341544a0

31. Spinelli S, Desmyter A, Frenken L, Verrips T, Tegoni M, Cambillau C. Domain swapping of a llama $\mathrm{V}_{\mathrm{H}} \mathrm{H}$ domain builds a crystal-wide beta-sheet structure. FEBS Lett (2004) 564:35-40. doi:10.1016/S0014-5793(04)00304-7

32. Decanniere K, Desmyter A, Lauwereys M, Ghahroudi MA, Muyldermans S, Wyns L. A single-domain antibody fragment in complex with RNase A: non-canonical loop structures and nanomolar affinity using two CDR loops. Structure (1999) 7:361-70. doi:10.1016/S0969-2126(99)80049-5

33. Desmyter A, Spinelli S, Payan F, Lauwereys M, Wyns L, Muyldermans S, et al. Three camelid $\mathrm{V}_{\mathrm{H}} \mathrm{H}$ domains in complex with porcine pancreatic $\alpha$-amylase: inhibition and versatility of binding topology. J Biol Chem (2002) 277:23645-50. doi:10.1074/jbc.M202327200

34. Desmyter A, Decanniere K, Muyldermans S, Wyns L. Antigen specificity and high affinity binding provided by one single loop of a camel single-domain antibody. J Biol Chem (2001) 276:26285-90. doi:10.1074/jbc.M102107200

35. Perez JM, Renisio JG, Prompers JJ, van Platerink CJ, Cambillau C, Darbon H, et al. Thermal unfolding of a llama antibody fragment: a two-state reversible process. Biochemistry (2001) 40:74-83. doi:10.1021/bi0009082

36. Dumoulin M, Conrath K, Van Meirhaeghe A, Meersman F, Heremans K, Frenken LG, et al. Single-domain antibody fragments with high conformational stability. Protein Sci (2002) 11:500-15. doi:10.1110/ps.34602

37. Verheesen P, ten Haaft MR, Lindner N, Verrips CT, de Haard JJ. Beneficial properties of single-domain antibody fragments for application in immunoaffinity purification and immuno-perfusion chromatography. Biochim Biophys Acta (2003) 1624:21-8. doi:10.1016/j.bbagen.2003.09.006

38. Eyer L, Hruska K. Single-domain antibody fragments derived from heavychain antibodies: a review. Vet Med (2012) 9:439-513.

39. Steeland S, Vandenbroucke RE, Libert C. Nanobodies as therapeutics: big opportunities for small antibodies. Drug Discov Today (2016) 21:1076-113. doi:10.1016/j.drudis.2016.04.003

40. D’Huyvetter M, Aerts A, Xavier C, Vaneycken I, Devoogdt N, Gijs M, et al. Development of ${ }^{177} \mathrm{Lu}$-nanobodies for radioimmunotherapy of HER2positive breast cancer: evaluation of different bifunctional chelators. Contrast Media Mol Imaging (2012) 7:254-64. doi:10.1002/cmmi.491

41. Wesolowski J, Alzogaray V, Reyelt J, Unger M, Juarez K, Urrutia M, et al. Single domain antibodies: promising experimental and therapeutic tools in infection and immunity. Med Microbiol Immunol (2009) 198:157-74. doi:10.1007/s00430-009-0116-7

42. Saerens D, Ghassabeh GH, Muyldermans S. Single-domain antibodies as building blocks for novel therapeutics. Curr Opin Pharmacol (2008) 8:600-8. doi:10.1016/j.coph.2008.07.006

43. Chakravarty R, Goel S, Cai W. Nanobody: the "magic bullet" for molecular imaging? Theranostics (2014) 4:386-98. doi:10.7150/thno.8006

44. Fernandes CFC, Pereira SDS, Luiz MB, Zuliani JP, Furtado GP, Stabeli RG. Camelid single-domain antibodies as an alternative to overcome challenges related to the prevention, detection, and control of neglected tropical diseases. Front Immunol (2017) 8:653. doi:10.3389/fimmu.2017.00653

45. Holt LJ, Herring C, Jespers LS, Woolven BP, Tomlinson IM. Domain antibodies: proteins for therapy. Trends Biotechnol (2003) 21:484-90. doi:10.1016/j. tibtech.2003.08.007

46. Harmsen MM, van Solt CB, Fijten HP, van Keulen L, Rosalia RA, Weerdmeester K, et al. Passive immunization of guinea pigs with llama single-domain antibody fragments against foot-and-mouth disease. Vet Microbiol (2007) 120:193-206. doi:10.1016/j.vetmic.2006.10.029

47. Vaneycken I, D’Huyvetter M, Hernot S, De Vos J, Xavier C, Devoogdt N, et al. Immuno-imaging using nanobodies. Curr Opin Biotechnol (2011) 22:877-81. doi:10.1016/j.copbio.2011.06.009

48. Hassanzadeh-Ghassabeh G, Devoogdt N, De Pauw P, Vincke C, Muyldermans S. Nanobodies and their potential applications. Nanomedicine (Lond) (2013) 8:1013-26. doi:10.2217/nnm.13.86

49. Vincke C, Loris R, Saerens D, Martinez-Rodriguez S, Muyldermans S, Conrath K. General strategy to humanize a camelid single-domain antibody and identification of a universal humanized nanobody scaffold. J Biol Chem (2009) 284:3273-84. doi:10.1074/jbc.M806889200

50. Papadopoulos KP, Isaacs R, Bilic S, Kentsch K, Huet HA, Hofmann M, et al. Unexpected hepatotoxicity in a phase I study of TAS266, a novel tetravalent agonistic Nanobody ${ }^{(\mathbb{R})}$ targeting the DR5 receptor. Cancer Chemother Pharmacol (2015) 75:887-95. doi:10.1007/s00280-015-2712-0

51. McGonigal K, Tanha J, Palazov E, Li S, Gueorguieva-Owens D, Pandey S. Isolation and functional characterization of single domain antibody modulators of caspase-3 and apoptosis. Appl Biochem Biotechnol (2009) 157:226-36. doi:10.1007/s12010-008-8266-4

52. Staus DP, Wingler LM, Strachan RT, Rasmussen SG, Pardon E, Ahn S, et al. Regulation of $\beta 2$-adrenergic receptor function by conformationally selective single-domain intrabodies. Mol Pharmacol (2014) 85:472-81. doi:10.1124/ mol.113.089516

53. Stijlemans B, Conrath K, Cortez-Retamozo V, Van Xong H, Wyns L, Senter P, et al. Efficient targeting of conserved cryptic epitopes of infectious agents by single domain antibodies: African trypanosomes as paradigm. J Biol Chem (2004) 279:1256-61. doi:10.1074/jbc.M307341200

54. Bradley ME, Dombrecht B, Manini J, Willis J, Vlerick D, De Taeye S, et al. Potent and efficacious inhibition of CXCR2 signaling by biparatopic nanobodies combining two distinct modes of action. Mol Pharmacol (2015) 87:251-62. doi:10.1124/mol.114.094821

55. Manglik A, Kobilka BK, Steyaert J. Nanobodies to study G protein-coupled receptor structure and function. Annu Rev Pharmacol Toxicol (2017) 57:19-37. doi:10.1146/annurev-pharmtox-010716-104710

56. Baker M. Upping the ante on antibodies. Nat Biotechnol (2005) 23:1065-72. doi:10.1038/nbt0905-1065

57. Beghein E, Gettemans J. Nanobody technology: a versatile toolkit for microscopic imaging, protein-protein interaction analysis, and protein function exploration. Front Immunol (2017) 8:771. doi:10.3389/fimmu.2017. 00771

58. Rossey I, Gilman MS, Kabeche SC, Sedeyn K, Wrapp D, Kanekiyo M, et al. Potent single-domain antibodies that arrest respiratory syncytial virus fusion protein in its prefusion state. Nat Commun (2017) 8:14158. doi:10.1038/ ncomms 14158

59. Darling TL, Sherwood LJ, Hayhurst A. Intracellular crosslinking of filoviral nucleoproteins with Xintrabodies restricts viral packaging. Front Immunol (2017) 8:1197. doi:10.3389/fimmu.2017.01197

60. Holliger P, Hudson PJ. Engineered antibody fragments and the rise of single domains. Nat Biotechnol (2005) 23:1126-36. doi:10.1038/nbt1142

61. Vanlandschoot P, Stortelers C, Beirnaert E, Ibanez LI, Schepens B, Depla E, et al. Nanobodies ${ }^{(\mathrm{R})}$ : new ammunition to battle viruses. Antiviral Res (2011) 92:389-407. doi:10.1016/j.antiviral.2011.09.002

62. Unciti-Broceta JD, Del Castillo T, Soriano M, Magez S, Garcia-Salcedo JA. Novel therapy based on camelid nanobodies. Ther Deliv (2013) 4:1321-36. doi: $10.4155 /$ tde. 13.87

63. De Meyer T, Muyldermans S, Depicker A. Nanobody-based products as research and diagnostic tools. Trends Biotechnol (2014) 32:263-70. doi:10.1016/j.tibtech.2014.03.001

64. Helma J, Cardoso MC, Muyldermans S, Leonhardt H. Nanobodies and recombinant binders in cell biology. JCell Biol (2015) 209:633-44. doi:10.1083/jcb.201409074

65. Bever CS, Dong JX, Vasylieva N, Barnych B, Cui Y, Xu ZL, et al. $\mathrm{V}_{\mathrm{H}} \mathrm{H}$ antibodies: emerging reagents for the analysis of environmental chemicals. Anal Bioanal Chem (2016) 408:5985-6002. doi:10.1007/s00216-016-9585-x

66. Li J, Zhu Z. Research and development of next generation of antibody-based therapeutics. Acta Pharmacol Sin (2010) 31:1198-207. doi:10.1038/ aps.2010.120

67. Mazor Y, Sachsenmeier KF, Yang C, Hansen A, Filderman J, Mulgrew K, et al. Enhanced tumor-targeting selectivity by modulating bispecific antibody binding affinity and format valence. Sci Rep (2017) 7:40098. doi:10.1038/ srep40098

68. Holliger P, Winter G. Engineering bispecific antibodies. Curr Opin Biotechnol (1993) 4:446-9. doi:10.1016/0958-1669(93)90010-T

69. Rozan C, Cornillon A, Petiard C, Chartier M, Behar G, Boix C, et al. Singledomain antibody-based and linker-free bispecific antibodies targeting FcyRIII induce potent antitumor activity without recruiting regulatory T cells. Mol Cancer Ther (2013) 12:1481-91. doi:10.1158/1535-7163.MCT$12-1012$ 
70. Muruganandam A, Tanha J, Narang S, Stanimirovic D. Selection of phage-displayed llama single-domain antibodies that transmigrate across human blood-brain barrier endothelium. FASEB J (2002) 16:240-2.

71. Abulrob A, Sprong H, Van Bergen en Henegouwen P, Stanimirovic D. The blood-brain barrier transmigrating single domain antibody: mechanisms of transport and antigenic epitopes in human brain endothelial cells. J Neurochem (2005) 95:1201-14. doi:10.1111/j.1471-4159.2005.03463.x

72. Li T, Bourgeois JP, Celli S, Glacial F, Le Sourd AM, Mecheri S, et al. Cellpenetrating anti-GFAP $\mathrm{V}_{\mathrm{H}} \mathrm{H}$ and corresponding fluorescent fusion protein $\mathrm{V}_{\mathrm{H}} \mathrm{H}$-GFP spontaneously cross the blood-brain barrier and specifically recognize astrocytes: application to brain imaging. FASEB J (2012) 26:3969-79. doi:10.1096/fj.11-201384

73. Webster CI, Caram-Salas N, Haqqani AS, Thom G, Brown L, Rennie K, et al. Brain penetration, target engagement, and disposition of the blood-brain barrier-crossing bispecific antibody antagonist of metabotropic glutamate receptor type 1. FASEB J (2016) 30:1927-40. doi:10.1096/f.201500078

74. Moutel S, Bery N, Bernard V, Keller L, Lemesre E, de Marco A, et al. NaLi-H1: a universal synthetic library of humanized nanobodies providing highly functional antibodies and intrabodies. Elife (2016) 5:e16228. doi:10.7554/ eLife. 16228

75. Monegal A, Ami D, Martinelli C, Huang H, Aliprandi M, Capasso P, et al. Immunological applications of single-domain llama recombinant antibodies isolated from a naive library. Protein Eng Des Sel (2009) 22:273-80. doi:10.1093/protein/gzp002

76. Goldman ER, Anderson GP, Liu JL, Delehanty JB, Sherwood LJ, Osborn LE, et al. Facile generation of heat-stable antiviral and antitoxin single domain antibodies from a semisynthetic llama library. Anal Chem (2006) 78:8245-55. doi:10.1021/ac0610053

77. Yan J, Li G, Hu Y, Ou W, Wan Y. Construction of a synthetic phage-displayed nanobody library with CDR3 regions randomized by trinucleotide cassettes for diagnostic applications. J Transl Med (2014) 12:343. doi:10.1186/ s12967-014-0343-6

78. Ladenson RC, Crimmins DL, Landt Y, Ladenson JH. Isolation and characterization of a thermally stable recombinant anti-caffeine heavy-chain antibody fragment. Anal Chem (2006) 78:4501-8. doi:10.1021/ac058044j

79. Spinelli S, Frenken LG, Hermans P, Verrips T, Brown K, Tegoni M, et al. Camelid heavy-chain variable domains provide efficient combining sites to haptens. Biochemistry (2000) 39:1217-22. doi:10.1021/bi991830w

80. Smolarek D, Hattab C, Hassanzadeh-Ghassabeh G, Cochet S, Gutierrez C, de Brevern AG, et al. A recombinant dromedary antibody fragment $\left(\mathrm{V}_{\mathrm{H}} \mathrm{H}\right.$ or nanobody) directed against human Duffy antigen receptor for chemokines. Cell Mol Life Sci (2010) 67:3371-87. doi:10.1007/s00018-010-0387-6

81. Traenkle B, Emele F, Anton R, Poetz O, Haeussler RS, Maier J, et al. Monitoring interactions and dynamics of endogenous $\beta$-catenin with intracellular nanobodies in living cells. Mol Cell Proteomics (2015) 14:707-23. doi:10.1074/mcp.M114.044016

82. van der Linden RH, Frenken LG, de Geus B, Harmsen MM, Ruuls RC, Stok W, et al. Comparison of physical chemical properties of llama $V_{H} H$ antibody fragments and mouse monoclonal antibodies. Biochim Biophys Acta (1999) 1431:37-46. doi:10.1016/S0167-4838(99)00030-8

83. Doyle PJ, Arbabi-Ghahroudi M, Gaudette N, Furzer G, Savard ME, Gleddie S, et al. Cloning, expression, and characterization of a single-domain antibody fragment with affinity for 15-acetyl-deoxynivalenol. Mol Immunol (2008) 45:3703-13. doi:10.1016/j.molimm.2008.06.005

84. Maussang D, Mujic-Delic A, Descamps FJ, Stortelers C, Vanlandschoot P, Stigter-van Walsum M, et al. Llama-derived single variable domains (nanobodies) directed against chemokine receptor CXCR7 reduce head and neck cancer cell growth in vivo. J Biol Chem (2013) 288:29562-72. doi:10.1074/ jbc.M113.498436

85. McCoy LE, Rutten L, Frampton D, Anderson I, Granger L, BashfordRogers R, et al. Molecular evolution of broadly neutralizing llama antibodies to the CD4-binding site of HIV-1. PLoS Pathog (2014) 10:e1004552. doi:10.1371/journal.ppat.1004552
86. Peyrassol X, Laeremans T, Gouwy M, Lahura V, Debulpaep M, Van Damme J, et al. Development by genetic immunization of monovalent antibodies (nanobodies) behaving as antagonists of the human ChemR23 receptor. J Immunol (2016) 196:2893-901. doi:10.4049/jimmunol.1500888

87. Liu S, Wang S, Lu S. DNA immunization as a technology platform for monoclonal antibody induction. Emerg Microbes Infect (2016) 5:e33. doi:10.1038/ emi.2016.27

88. Nguyen VK, Zou X, Lauwereys M, Brys L, Bruggemann M, Muyldermans S. Heavy-chain only antibodies derived from dromedary are secreted and displayed by mouse B cells. Immunology (2003) 109:93-101. doi:10.1046/j. 1365-2567.2003.01633.x

89. Zou X, Smith JA, Nguyen VK, Ren L, Luyten K, Muyldermans S, et al. Expression of a dromedary heavy chain-only antibody and B cell development in the mouse. J Immunol (2005) 175:3769-79. doi:10.4049/jimmunol. 175.6.3769

90. Janssens R, Dekker S, Hendriks RW, Panayotou G, van Remoortere A, San JK, et al. Generation of heavy-chain-only antibodies in mice. Proc Natl Acad Sci US A (2006) 103:15130-5. doi:10.1073/pnas.0601108103

91. Kohler G, Milstein C. Continuous cultures of fused cells secreting antibody of predefined specificity. Nature (1975) 256:495-7. doi:10.1038/256495a0

92. Prentice HG, Blacklock HA, Janossy G, Bradstock KF, Skeggs D, Goldstein G, et al. Use of anti-T-cell monoclonal antibody OKT3 to prevent acute graftversus-host disease in allogeneic bone-marrow transplantation for acute leukaemia. Lancet (1982) 1:700-3. doi:10.1016/S0140-6736(82)92619-8

93. Cosimi AB, Colvin RB, Burton RC, Rubin RH, Goldstein G, Kung PC, et al. Use of monoclonal antibodies to T-cell subsets for immunologic monitoring and treatment in recipients of renal allografts. N Engl J Med (1981) 305:308-14. doi:10.1056/NEJM198108063050603

94. Beck A, Wurch T, Bailly C, Corvaia N. Strategies and challenges for the next generation of therapeutic antibodies. Nat Rev Immunol (2010) 10:345-52. doi: $10.1038 /$ nri2747

95. Ecker DM, Jones SD, Levine HL. The therapeutic monoclonal antibody market. MAbs (2015) 7:9-14. doi:10.4161/19420862.2015.989042

96. Winter G, Griffiths AD, Hawkins RE, Hoogenboom HR. Making antibodies by phage display technology. Annu Rev Immunol (1994) 12:433-55. doi:10.1146/annurev.iy.12.040194.002245

97. Hoogenboom HR. Selecting and screening recombinant antibody libraries. Nat Biotechnol (2005) 23:1105-16. doi:10.1038/nbt1126

98. Nelson AL, Reichert JM. Development trends for therapeutic antibody fragments. Nat Biotechnol (2009) 27:331-7. doi:10.1038/nbt0409-331

99. McCafferty J, Griffiths AD, Winter G, Chiswell DJ. Phage antibodies: filamentous phage displaying antibody variable domains. Nature (1990) 348:552-4. doi:10.1038/348552a0

100. Jespers LS, Roberts A, Mahler SM, Winter G, Hoogenboom HR. Guiding the selection of human antibodies from phage display repertoires to a single epitope of an antigen. Biotechnology (N Y) (1994) 12:899-903.

101. Kempeni J. Preliminary results of early clinical trials with the fully human anti-TNF- $\alpha$ monoclonal antibody D2E7. Ann Rheum Dis (1999) 58 (Suppl 1):I70-2. doi:10.1136/ard.58.2008.i70

102. Wang Y, Fan Z, Shao L, Kong X, Hou X, Tian D, et al. Nanobody-derived nanobiotechnology tool kits for diverse biomedical and biotechnology applications. Int J Nanomedicine (2016) 11:3287-303. doi:10.2147/IJN.S107194

Conflict of Interest Statement: The author declares that the research was conducted in the absence of any commercial or financial relationships that could be construed as a potential conflict of interest.

Copyright (c) 2017 Arbabi-Ghahroudi. This is an open-access article distributed under the terms of the Creative Commons Attribution License (CC BY). The use, distribution or reproduction in other forums is permitted, provided the original author(s) or licensor are credited and that the original publication in this journal is cited, in accordance with accepted academic practice. No use, distribution or reproduction is permitted which does not comply with these terms. 